\title{
Effect of Trade Liberalisation on Wage Inequality in Indonesia
}

\author{
Watekhi ${ }^{\mathrm{a}}$ \\ Statistics Indonesia \\ Nachrowi D. Nachrowi ${ }^{b}$ \\ Universitas Indonesia \\ Djoni Hartono ${ }^{c}$ \\ Universitas Indonesia \\ Arie Damayantid \\ Universitas Indonesia
}

\begin{abstract}
This study attempts to find out the influence of trade liberalisation on wage inequality in Indonesia. A two-stage estimation approach is used. Using the national labour force survey dataset, the study estimates industry wage premium and industryspecific skill premium in the first stage conditional on individual worker characteristics. In the second stage, the study regresses industry wage premium and industry-specific skill premium on tariff as a measure of trade liberalisation, respectively. It is concluded that trade liberalisation significantly contributes to increasing wage inequality. This contribution occurred through changes in industry wage premium but not industryspecific skill premium.
\end{abstract}

Keywords: Industry-specific skill premium, trade liberalisation, wage inequality, wage premium

JEL classification: F14, F16, J31

\section{Introduction}

International trade theory, Heckscher-Ohlin-Samuelson (HOS) model, predicts that countries with relatively abundant production factors will export commodities and import commodities where production factors are relatively scarce (Baldwin, 1971). Based on these predictions, developing countries will export labour-intensive (unskilled) and import capital-intensive (skilled) commodities, and vice versa for developed

a Statistics Indonesia, Jl. Dr. Sutomo 6-8, Jakarta 10710, Indonesia. The author is also affiliated to Faculty of Economics and Business, Universitas Indonesia. Email: watekhi@bps.go.id

b Faculty of Economics and Business, Universitas Indonesia, Kampus Baru UI Depok, Jawa Barat - 16424, Indonesia. Email: nachrowi@ui.ac.id; gnachrowi@gmail.com (Corresponding author)

c Faculty of Economics and Business, Universitas Indonesia, Kampus Baru UI Depok, Jawa Barat - 16424, Indonesia. Email: djoni.hartono@ui.ac.id

d Faculty of Economics and Business, Universitas Indonesia, Kampus Baru UI Depok, Jawa Barat - 16424, Indonesia. Email: ari.damayanti@ui.ac.id

Article Info: Received 20 September 2017; Revised 11 May 2018; Accepted 8 September 2018 https://doi.org/10.22452/MJES.vol55no2.4 
countries. Furthermore, changes in the relative price of a commodity will affect factor prices. Thus, a change in tariff will change the price of production factor.

Due to abundant unskilled labour in developing countries, trade liberalisation is expected to increase exports of labour-intensive commodities. This condition will contribute to increases in commodity prices, unskilled labour demand, and unskilled workers' relative wage. So, it will generally increase real wages. Therefore, it is predicted to decrease wage inequality.

Not all studies regarding effects of trade liberalisation on the inequality of wage is in line with the HOS theory, especially in the case of developing countries. For instance, a study done by Goldberg and Pavcnik (2007) found that wage inequality increased due to globalisation. The same results are reported by the work of Lee and Wie (2015) and USAID (June 2006). Meanwhile, other studies like Amiti and Cameron (2012), concluded that trade liberalisation has no impact or even reduce wage inequality. Therefore, research on the impacts of trade liberalisation on wage inequality can be interesting through various channels.

The most commonly used channel is wage differences due to skills (skill premium). The increase in skill premium as a result of trade liberalisation is preceded by an increase in relative demand for skilled labour. This increase is attributed to the import of high-tech capital goods (Robbins, 1996), intermediate goods trade (Feenstra \& Hanson, 2001), defensive innovations for companies in response to import competition due to trade liberalisation (Wood, 1995) and the mechanisms represented by technological change models as endogenous technological change (Acemoglu, 2003). Related researches are Cragg and Epelbaum (1995) for Mexico, Galiani and Sanguinetti (2003) for Argentina, Attanasio, Goldberg and Pavcnik (2004) for Colombia, Gonzaga, Menezes Filho and Terra (2006) and Pavcnik, Blom, Goldberg and Schady (2004) for Brazil, Amiti and Cameron (2012) and Lee and Wie (2015) for Indonesia. However, results of the studies are not uniform in explaining the impacts of trade liberalisation on skill premium.

In Indonesia, studies of the impacts of trade liberalisation on wage inequality use the skill premium channel. Lee and Wie (2015) stated that trade liberalisation increases skill premium. Amiti and Cameron (2012) stated that reducing import tariff of intermediate inputs reduces skill premium, but reducing the final goods tariff does not affect skill premium. Both studies are only for the manufacturing industry. Its concentration is on the return of specific characteristics of the workers (i.e. skill) under the assumption that workers can move between sectors. This condition will be suitable in the long run. In the short and medium term, it is not possible for workers to switch between sectors (Goldberg \& Pavcnik, 2005). Thus, looking at wage inequality through skill premium at economy-wide level cannot measure the role of the industry where individuals work.

In examining the influence of trade liberalisation on wage inequality in Indonesia, the channels used in this study are industry wage premium ${ }^{1}$ and industry-specific skill

1 Industry wage premium is the portion of individual wages that cannot be explained by the characteristics of the worker, company or employment but can be explained by industry characteristics (sector) of work. 
premium for all sectors involved in trades (tradable sector). Understanding the linkage of trade liberalisation with industry wage premium is essential for several reasons. First, is the less flexible labour market. The Global Competitiveness Report on labour market flexibility reported that Indonesia ranks 131 of 140 countries in the world (Schwab \& Sala-i-Martín, 2015). In a rigid labour market, it is difficult for workers to move from one economic activity (sector) to other economic activities quickly and at low cost. In addition, the possibility of wage fluctuations based on labour productivity without causing social disturbances is difficult. So, analysing wages based on an industry is very suitable in order to see the impact of trade liberalisation on wages in the short and medium term. Considering industrial relations in examining the effects of trade policy on wage distribution is essential in order to see the key flows in between.

Second, knowing the impacts of trade liberalisation on industry wage premium will reveal the wage inequality based on workers' education specifically in an industry. Since each industry has a distinct portion of the number of skilled and unskilled workers, a change in the industry wage premium will impact on relative wage of skilled and unskilled labour. A decline of the tariff in labour-intensive industries, and reduction of relative wage as an impact of trade liberalisation will reduce the relative wages of unskilled workers. This influence will be different if only the impact of trade liberalisation on the premium skill at economy-wide level is studied.

Furthermore, industry wage premium will vary among workers with different levels of skills. For example, the skilled workers will have special expertise in a particular sector, or have a high bargaining value in terms of wages. If wage differs between workers with varying skill, and if trade liberalisation improves industry-specific skill premium, this will add another channel to the impacts of trade liberalisation on wage inequality.

The study uses employee data from the National Labour Force Survey (SAKERNAS) year 2000, 2005 and 2010, which is combined with tariffs at the industry level for tradable sectors. It is concluded that trade liberalisation significantly contributes to increasing wage inequality. This contribution occurred through changes in industry wage premium but not industry-specific skill premium.

The paper is structured as follows. The next section presents an overview of trade liberalisation, wage and employment in Indonesia. Section 3 provides a brief review of the literature on trade liberalisation and wage inequality. Section 4 discusses the data and methodology. Section 5 describes the results of the empirical analysis and Section 6 concludes.

\section{Indonesia's Trade Liberalisation, Inequality and Employment}

In 1965, Indonesia started to set up its foreign trade policy (Pangestu, Rahardja, \& Ing, 2015). After the 1990s, the degree of trade liberalisation increased which was affected by the ASEAN Free Trade Area in 1991, Asia-Pacific Economic Cooperation in 1994, and formation of the World Trade Organization in 1995. Trade policy became more open after the International Monetary Fund (IMF) played a role in assisting the recovery program from the East Asia and Southeast Asia economic crisis in 1997-1998. Since 2000, trade liberalisation policies have become more pronounced through several indicators, 


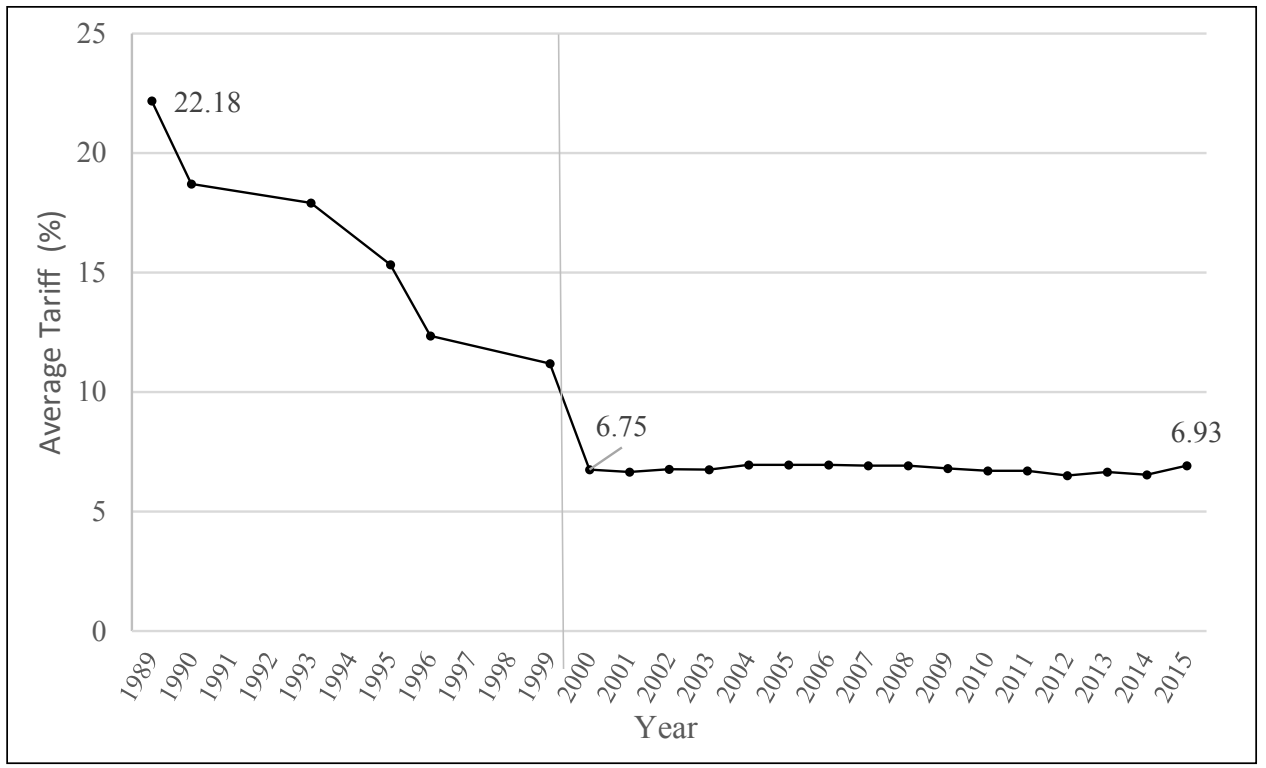

Figure 1. Indonesia's Average Tariff (1989-2015)

Source: Authors' computation based on data from World Trade Organization.

including Indonesia's lowest level of protection compared to other Asian countries including Thailand; tariff reductions continue to be in place, and the government has been able to keep the average tariff at less than 10 percent (Basri \& Patunru, 2012). Figure 1 shows a tariff reduction from 22.18 percent in 1989 to 6.75 percent in 2000 .

Along with increasing trade liberalisation, Indonesia's economic growth was generally positive except during the economic crisis in 1997-1998 (BPS, 2015). However, income inequality has increased rapidly compared to East Asia and other Southeast Asia countries. For example, the Gini coefficient of income is 0.30 in 2000 (one of the lowest in the region), which increased to 0.41 in 2013 (World Bank, March 2016). Furthermore, consumption per person for 10 percent of the richest grew by 6 percent per year between 2003 and 2010, while growing by less than 2 percent for 40 percent of the poorest. The Gini coefficient of wage increased from 0.41 to 0.45 between 2001 and 2012, and from 0.39 to 0.43 for formal workers (World Bank, 2014). The average Gini wage coefficient is 22 percent higher than the Gini coefficient of income from 2001 to 2012 (Tadjoeddin, 2016).

The wage and employment data are examined by industry. Table 1 describes average (real hourly) wages, inequality of wages and employment shares for five major tradable sectors. The real hourly wages rose between 2000 and 2010, as shown in columns 1 and 2 . The wage increased by an average of 3.93 percent per year. ${ }^{2}$ The wage growth between industries varies considerably. Agricultural labourers as the lowest wage group have an average wage growth of 4.6 percent per year; on the contrary,

2 We also compute the annual wage growth from 2000 to 2010. Computation results are available on request. 
Table 1. Wage, wage inequality and employment structure in tradable sectors, 2000 and 2010

\begin{tabular}{|c|c|c|c|c|c|c|}
\hline \multirow[t]{2}{*}{ Industry group } & \multicolumn{2}{|c|}{$\begin{array}{l}\text { Average hourly } \\
\text { wage (Rupiahs) }\end{array}$} & \multicolumn{2}{|c|}{$\begin{array}{c}\text { Gini } \\
\text { coefficient }\end{array}$} & \multicolumn{2}{|c|}{$\begin{array}{l}\text { Share of wage } \\
\text { employment (\%) }\end{array}$} \\
\hline & 2000 & 2010 & 2000 & 2010 & 2000 & 2010 \\
\hline Agriculture & 2,981 & 4,492 & 0.335 & 0.358 & 38.0 & 33.9 \\
\hline Mining/quarrying & 6,615 & 8,773 & 0.487 & 0.474 & 1.9 & 9.3 \\
\hline Manufacturing & 3,935 & 4,678 & 0.351 & 0.378 & 52.4 & 45.1 \\
\hline Other business activities & 6,213 & 7,676 & 0.433 & 0.438 & 1.8 & 1.9 \\
\hline Services & 3,747 & 4,599 & 0.381 & 0.420 & 5.8 & 9.8 \\
\hline Overall & 3,654 & 5,046 & 0.365 & 0.405 & 100 & 100 \\
\hline
\end{tabular}

Note: ISIC code for Agriculture: 01, 02, 05; Mining/quarrying: 10 to 14; Manufacturing: 15 to 36; Other business activities: 75; Services: 92, 93, 99.

Source: Authors' computation based on National Labour Force Survey data of Indonesia.

mining workers as those who constantly get the best stipends have a growth of 3.25 percent of wages per year. Columns 3 and 4 describe how the wage evolved across the five sectors. Generally, wage inequality increased between 2000 and 2010. Gini coefficient raised from 0.365 to 0.405 . Wage inequality also tended to increase for all industry groups except mining/quarrying. Finally, columns 5 and 6 show that the largest increase in employment shares is in mining/quarrying; while the largest decrease has been in manufacturing.

\section{Trade Liberalisation, Industry Wage Premium and Industry-specific Skill Premium}

\subsection{Trade Liberalisation and Industry Wage Premium}

The impacts of trade liberalisation on the industry wage premium can be explained through the following channels: first, in perfectly competitive factor product markets, the impact of trade liberalisation on wage distribution refers to specific factors (short-term) and the Ricardo-Viner (medium-term) model. Both predict that sectors experiencing relatively large reductions in import tariffs will experience a decrease in wages relative to the average wage in the economy. In the short- and medium-term models, it is not easy for labour to move between sectors, and the wage of workers depends on the price of the products and the marginal products of labour in the industry. The model predicts that a decrease in industry tariffs leads to a proportional decrease in industrial wages.

Second, the imperfect competition market provides an additional perspective on how international trade policy can affect wages. The existence of trade liberalisation opens greater opportunities in importing all kinds of goods including capital goods, finished goods and semi-finished goods. This condition allows domestic companies to replace the services of workers by importing input goods or products. Thereby, labour's dealing power in confronting the capital owner could be attenuated due to 
trade liberalisation, in terms of rent sharing. Rodrik (1998) implied that wage inequality increases as labour's dealing power declines due to globalisation.

Third, trade liberalisation will increase the productivity of industry (Melitz, 2003). This theory is supported by empirical findings of Eslava, Haltiwanger, Kugler and Kugler (2013), Harrison, Martin and Nataraj (2012), Jacob and Meister (2005) and Nataraj (2011). Specifically for Indonesia, Amiti and Konings (2007) estimated an increase in productivity gained from the reduction of final and intermediate goods tariffs in Indonesia between 1991 and 2001. The increase in productivity affects wage increases (De Locker, 2007). This means that the relative wages of an industry positively correlates to trade liberalisation.

Although consolidation of industries serves as a necessary channel where policies on trade may influence labour's wages, it does not predict the way in which the effects are expected from trade liberalisation on the industry wage premium. Therefore, it needs to be proven empirically.

\subsection{Trade Liberalisation and Industry-specific Skill Premium}

Since each industry has a different proportion of skilled and unskilled labour, changes in the industry wage premium will have an impact on changes in relative wages of skilled and unskilled labour. Reduction of the tariff in labour-intensive industries, and the decline of relative wage as an impact of trade liberalisation will lower the relative wages of unskilled workers. The effect may be different from the influence raised by trade liberalisation on skill premium.

\section{Empirical Model}

We use an industry wage premium methodology to estimate the effect of trade liberalisation on wages. We refer to Mehta and Hasan (2012) who used a two-stage estimation. The idea is to capture variations in inter-industry wages and industryspecific skill premium and using tariffs over time to identify the impacts of trade liberalisation on wages.

\subsection{Stage 1}

In the first stage, industry wage and skill premium are constructed by estimating the following wage model separately for each year:

$$
\ln \left(\mathrm{w}_{j i}\right)=\mathbf{C}_{j i}^{\prime} \beta+\sum_{t=1}^{\prime}\left(i w p_{i}+i s w p_{i} \operatorname{Tr}_{j}\right) S_{i}+\varepsilon_{j i}
$$

where $w_{j i}$ is real wages for worker $j$ in industry affiliation $i, T_{j}$ indicates that worker $j$ is skilled (i.e. they have a diploma or higher qualification), and $S_{i}$ means they work in subsector $i$. There are $i=35$ industries in total. To keep dummies for all 35 sub-sectors, the constant in this model is omitted. Thus $i w p_{i}$, the industry wage premium, captures an unskilled worker's wage in subsector $i$, normalised for the $\mathbf{C}$ variables. Vector $\mathbf{C}$ includes primary, junior secondary and senior secondary education that is recorded as a series of dummies capturing the highest level completed, with uneducated level 
(not yet graduated from primary school or less) as the omitted category. Reversion of education is confirmed relative to the uneducated workers' wage. The $i s w p_{i}$ is the industry-specific skill premium; it captures the relative stipends of university-educated workers towards uneducated workers in the particular sectors. The reversion of university level differs across sectors; while the reversion of low education does not. It is signified to maintain the latitude degree without blurring the skill premia role in directing inequality.

\subsection{Stage 2}

The first stage resulted in two sets of estimated coefficients; these are merged and regressed on an aggregate of trade-related industry features. There are two dependent variables at this stage: (i) the coefficient of industry premiums $\left(i w p_{i t}\right)$, and (ii) the coefficient of industry-specific skill premium (iswp $\left.p_{i t}\right)$.

Let $\operatorname{Trf}_{i t}$ denote tariff-barrier at time $t$ for industry $i$, then the second stage regression of merging the industry wage premium and industry-specific skill premium is estimated over the different industries and time periods:

$$
\begin{aligned}
& i w p_{i t}=\operatorname{Tr} f_{i t} \beta_{w}+\theta_{w i}+\theta_{w t}+u_{w i t} \\
& i s w p_{i t}=\operatorname{Tr} f_{i t} \beta_{s}+\theta_{s i}+\theta_{s t}+u_{s i t}
\end{aligned}
$$

Both fixed effect and random effect models are examined. The weighted least squares are used, whereby the reverse of estimated variances of the industry wage premium and industry-specific skill premium are utilised as weights.

\section{The Dataset}

Two sources of data are used in this study. The first is labour force survey data from the National Labour Force Survey of Indonesia (SAKERNAS), which is used to obtain information on national labour market characteristics of all working-age individuals within sampled households in the seven days before the survey. The survey is conducted annually and contains more than 200,000 individuals in most series. It is aimed to meet three objectives that are designed to discover: i) employment by age, gender, marital status, education, location of workers, wages, hours of work, occupations, industrial classification and employment status, ii) unemployment by different characteristics and efforts towards looking for work, iii) working age population not in the labour force (e.g., in schools, doing housekeeping and others). For the analysis, this study works with surveys conducted in August 2000, 2005 and 2010, where wage inequality of Indonesia increased since the early 2000s (Lee \& Wie, 2015). The study is restricted to the urban sectors of 34 provinces.

For wage analysis, the study considered all workers aged 15 and above who reported positive wage during the survey's reference. Since the study is interested in quantifying the importance of trade liberalisation in explaining overall changes in wage distribution, it will then only analyse employees in tradable sectors. This is an 
important difference between this analysis and those of Gonzaga, Menezes Filho and Terra (2006) and Pavcnik, Blom, Goldberg and Schady (2004) who focussed exclusively on workers in manufacturing, while Ferreira, Leite and Wai-Pow (2007) was for all workers. The study defines wage as hourly wages, the monthly salary is divided by four, and then divided by the average working hours per week. All monetary values are deflated with annual consumer price index for the provincial capital.

The study uses educational level ${ }^{3}$ to measure a worker's skill. In wage regressions, workers are grouped into five educational groups: not yet graduated from primary school or less, primary, junior secondary, senior secondary, and diploma/university. This variable is also used to build an indicator of dichotomous skill; categorising labourers as unskilled for those who went to high school or less, and as skilled for those who graduated from university.

The second dataset used in this study is the trade-related variable for 35 industries. The trade-related variable is HS1996 nominal tariffs from the World Trade Organization ${ }^{4}$. Because it covers all tradable sectors (not just the manufacturing sector), we use final goods tariffs. The HS1996 code is converted into Klasifikasi Baku Lapangan Usaha Indonesia 2000 (Standard Classification of Indonesian Business Field 2000) or KBLI2000, or ISIC Revision 3 (ISIC3). We then calculate the average rate based on ISIC3 level 2 (2 digits). Table 2 presents tariff values for the 35 industries into which the Indonesian firms have been grouped. There is no sample for mining of uranium and thorium ores, electricity, gas, steam and hot water supply industry; and there is no sample either for extra-territorial organisations and bodies industry for 2000.

Table 2. Industry tariffs for Indonesia

\begin{tabular}{lrlrrr}
\hline \multirow{2}{*}{$\begin{array}{l}\text { No. } \\
\text { code }\end{array}$} & \multicolumn{1}{c}{ Industry description } & \multicolumn{3}{c}{ Tariff (\%) } \\
\cline { 3 - 6 } & & 2000 & 2005 & 2010 \\
\hline 1 & 01 & Agriculture, hunting and related service activities & 4.57 & 4.74 & 4.97 \\
2 & 02 & Forestry, logging and related service activities & 3.06 & 1.64 & 3.24 \\
3 & 05 & Fishing, operation of fish hatcheries and fish farms; & 5.54 & 5.47 & 5.32 \\
& & service activities incidental to fishing & & & \\
4 & 10 & Mining of coal and lignite; extraction of peat & 5 & 5 & 5 \\
5 & 11 & Extraction of crude petroleum and natural gas; service & 3 & 2.5 & 2.5 \\
& & activities incidental to oil and gas extraction excluding & & & \\
6 & 12 & Murveying & & 5 & 5 \\
7 & 13 & Mining of uranium and thorium ores & 3.8 & 4.13 & 4.09 \\
8 & 14 & Other mining and quarrying & 3.8 & 3.9 & 3.53 \\
\hline
\end{tabular}

3 The highest educational level completed by a person verified with the receipt of a diploma or a letter of completion/certificate.

$4 \quad$ http://tariffdata.wto.org/ReportersAndProducts.aspx 
Table 2. Continued

\begin{tabular}{|c|c|c|c|c|c|}
\hline \multirow[t]{2}{*}{ No. } & \multirow{2}{*}{$\begin{array}{l}\text { ISIC } \\
\text { code }\end{array}$} & \multirow[t]{2}{*}{ Industry description } & \multicolumn{3}{|c|}{ Tariff $(\%)$} \\
\hline & & & 2000 & 2005 & 2010 \\
\hline 9 & 15 & Manufacture of food products and beverages & 11.27 & 15.17 & 14.31 \\
\hline 10 & 16 & Manufacture of tobacco products & 13 & 14.41 & 14.44 \\
\hline 11 & 17 & Manufacture of textiles & 9.23 & 9.59 & 9.67 \\
\hline 12 & 18 & Manufacture of wearing apparel & 13.45 & 13.75 & 14 \\
\hline 13 & 19 & $\begin{array}{l}\text { Tanning and dressing of leather; manufacture of luggage, } \\
\text { handbags, saddlery, harness and footwear }\end{array}$ & 7.8 & 7.59 & 10.94 \\
\hline 14 & 20 & $\begin{array}{l}\text { Manufacture of wood and products of wood and cork, } \\
\text { except furniture; manufacture of articles of straw and } \\
\text { plaiting materials }\end{array}$ & 2.86 & 4.69 & 3.94 \\
\hline 15 & 21 & Manufacture of paper and paper products & 3.9 & 4.42 & 4.48 \\
\hline 16 & 22 & Publishing, printing and reproduction of recorded media & 4.53 & 5 & 4.3 \\
\hline 17 & 23 & $\begin{array}{l}\text { Manufacture of coke, refined petroleum products and } \\
\text { nuclear fuel }\end{array}$ & 3.85 & 4.6 & 2.03 \\
\hline 18 & 24 & Manufacture of chemicals and chemical products & 4.82 & 5.28 & 4.68 \\
\hline 19 & 25 & Manufacture of rubber and plastics products & 11.35 & 13.22 & 11.95 \\
\hline 20 & 26 & Manufacture of other non-metallic mineral products & 5.91 & 7.33 & 6.86 \\
\hline 21 & 27 & Manufacture of basic metals & 7.49 & 8.46 & 6.54 \\
\hline 22 & 28 & $\begin{array}{l}\text { Manufacture of fabricated metal products, except } \\
\text { machinery and equipment }\end{array}$ & 9.85 & 10.93 & 9.53 \\
\hline 23 & 29 & Manufacture of machinery and equipment n.e.c. & 2.98 & 2.91 & 2.9 \\
\hline 24 & 30 & $\begin{array}{l}\text { Manufacture of office, accounting and computing } \\
\text { machinery }\end{array}$ & 1.67 & 1.63 & 1.43 \\
\hline 25 & 31 & Manufacture of electrical machinery and apparatus n.e.c. & 7.01 & 7.02 & 6.09 \\
\hline 26 & 32 & $\begin{array}{l}\text { Manufacture of radio, television and communication } \\
\text { equipment and apparatus }\end{array}$ & 5.25 & 6.25 & 5.43 \\
\hline 27 & 33 & $\begin{array}{l}\text { Manufacture of medical, precision and optical instruments, } \\
\text { watches and clocks }\end{array}$ & 4.77 & 4.62 & 4.64 \\
\hline 28 & 34 & Manufacture of motor vehicles, trailers and semi-trailers & 25.2 & 30.1 & 19.08 \\
\hline 29 & 35 & Manufacture of other transport equipment & 6.17 & 12.75 & 7.02 \\
\hline 30 & 36 & Manufacture of furniture, manufacturing n.e.c. & 10.82 & 11.2 & 10.53 \\
\hline 31 & 40 & Electricity, gas, steam and hot water supply & 3.33 & 3.33 & 3.33 \\
\hline 32 & 74 & Other business activities & 7.5 & 7.22 & 6.88 \\
\hline 33 & 92 & Recreational, cultural and sporting activities & 9.06 & 7.37 & 7.5 \\
\hline 34 & 93 & Other service activities & 5 & 5 & 5 \\
\hline 35 & 99 & Extra-territorial organisations and bodies & 4.51 & 5.92 & 5.52 \\
\hline
\end{tabular}

Note: n.e.c. - not elsewhere classified.

Source: World Trade Organization. 


\section{Results}

Before exploring the effects of trade liberalisation on industry wage premiums and industry-specific skill premiums, results of first-stage regressions are presented. The first-stage results show that several workers' characteristics are associated with higher real wages: age, being male, being married and education (Table 3). Gender roles decline over the years, indicating the beginning of gender equality. The role of age to wages also decreases over time. The return of education is in accordance with the level; the higher the level of education, the higher the wages. The role of workers' characteristics in this study is in line with previous studies (Ferreira et al., 2007; Kumar \& Mishra, 2008; Mehta \& Hasan, 2012; Pavcnik et al., 2004)

Available statistical values show that industrial relations significantly play a part in defining the difference of real hourly wages. Labour quality accounted for 54 percent of the total variety of log real hourly wages, in $2000 . R^{2}$ increased to 0.996 , due to the industrial indicator supplement to the regression. It is dependent on other labour qualities; as seen in Table 3, the indicators accounted for 46 percent of the variety in log hourly wages in 2000. Over all, industrial indicators reckoned for 28-46 percent of the difference in log real hourly stipends from 2000-2010.

Table 3. First-stage regression results for worker characteristics, 2000, 2005 and 2010

\begin{tabular}{|c|c|c|c|c|c|c|}
\hline \multirow{2}{*}{$\begin{array}{l}\text { Dependent } \\
\text { variable: } \\
\text { log(wage) }\end{array}$} & \multicolumn{2}{|c|}{2000} & \multicolumn{2}{|c|}{2005} & \multicolumn{2}{|c|}{2010} \\
\hline & Coef. & Std. err. & Coef. & Std. err. & Coef. & Std. err. \\
\hline Male & $0.230 * * *$ & 0.021 & $0.174 * * *$ & 0.018 & $0.163 * * *$ & 0.010 \\
\hline Age & $0.040 * * *$ & 0.005 & $0.037 * * *$ & 0.005 & $0.035^{* * *}$ & 0.002 \\
\hline Age Square & $-0.000 * * *$ & 0.000 & $-0.000 * * *$ & 0.000 & $-0.000 * * *$ & 0.000 \\
\hline Married & $0.056^{* *}$ & 0.024 & $0.101 * * *$ & 0.020 & $0.072 * * *$ & 0.011 \\
\hline \multicolumn{7}{|l|}{ Education } \\
\hline Primary & 0.048 & 0.038 & $0.333^{* * *}$ & 0.043 & $0.141 * * *$ & 0.018 \\
\hline Junior Secondary & $0.213 * * *$ & 0.041 & $0.554 * * *$ & 0.044 & $0.364 * * *$ & 0.018 \\
\hline Senior Secondary & $0.454 * * *$ & 0.039 & $0.812^{* * *}$ & 0.043 & $0.554 * * *$ & 0.017 \\
\hline Observations & & 3604 & & 6068 & & 20733 \\
\hline \multicolumn{7}{|c|}{ Statistic without industry indicators } \\
\hline $\mathrm{F}$ & & 604.213 & & 2154.532 & & 5477.240 \\
\hline P-Value (F) & & 0.000 & & 0.000 & & 0.000 \\
\hline $\mathrm{R}^{2}$ & & 0.540 & & 0.713 & & 0.649 \\
\hline Adjusted $\mathrm{R}^{2}$ & & 0.540 & & 0.713 & & 0.649 \\
\hline \multicolumn{7}{|c|}{ Statistic with industry indicators } \\
\hline $\mathrm{F}$ & & 1976.780 & & 3430.020 & & 3639.070 \\
\hline P-Value (F) & & 0.000 & & 0.000 & & 0.000 \\
\hline $\mathrm{R}^{2}$ & & 0.996 & & 0.996 & & 0.996 \\
\hline Adjusted $\mathrm{R}^{2}$ & & 0.996 & & 0.996 & & 0.996 \\
\hline
\end{tabular}

Note: $\quad * \mathrm{p}<.05 ; * * \mathrm{p}<.01 ; * * * \mathrm{p}<.001$.

Source: Authors' calculations based on SAKERNAS datasets. 


\subsection{Industry Wage Premium}

Estimation of industry wage premiums varies across industries (Table 4). In 2000, for example, it ranges from 7.770 for the manufacture of tobacco products (ISIC code=16) to 9.163 for mining of metal ores (ISIC code=13). Table 4 reports the standard deviations of the difference in industrial wages which sums up the volatility of wage premiums. Based on the standard deviation values, the smallest variation is in 2005 which is 0.254 while the largest is in 2000 which is 0.336 . The industry wage differences signify that transforming industries affect labour wages.

Industries employing a low share of unskilled workers, such as mining of metal ores (share of unskilled workers is 90.91 percent) tend to be the highest in industry wage premiums. While industries that employ a large share of unskilled workers, such as manufacture of tobacco products (share of unskilled workers is 98.04 percent) tend to be the lowest in industry wage premium. The correlation of industry wage premiums and unskilled labour shares within the industry are -0.18 (2000), -0.27 (2005) and -0.40 (2010). These indicate that the lowest share of unskilled workers resulted in the highest industry wage premium.

Table 4. Industry wage premiums (IWP), 2000, 2005 and 2010

\begin{tabular}{|c|c|c|c|c|c|c|}
\hline \multirow[t]{2}{*}{ Industry } & \multicolumn{2}{|c|}{2000} & \multicolumn{2}{|c|}{2005} & \multicolumn{2}{|c|}{2010} \\
\hline & IWP & Std. err. & IWP & Std. err. & IWP & Std. err. \\
\hline $\begin{array}{l}\text { Agriculture, hunting and related } \\
\text { service activities }\end{array}$ & $7.844 * * *$ & 0.027 & $7.940 * * *$ & 0.038 & $8.363^{* * *}$ & 0.017 \\
\hline $\begin{array}{l}\text { Forestry, logging and related } \\
\text { service activities }\end{array}$ & $8.605^{* * *}$ & 0.247 & $8.021 * * *$ & 0.134 & $8.674 * * *$ & 0.051 \\
\hline $\begin{array}{l}\text { Fishing, operation of fish } \\
\text { hatcheries and fish farms; } \\
\text { service activities incidental to } \\
\text { fishing }\end{array}$ & $8.051^{* * *}$ & 0.059 & $7.893 * * *$ & 0.053 & $8.194 * * *$ & 0.020 \\
\hline $\begin{array}{l}\text { Mining of coal and lignite; } \\
\text { extraction of peat }\end{array}$ & $8.539 * * *$ & 0.319 & $8.321^{* * *}$ & 0.084 & $9.049 * * *$ & 0.030 \\
\hline $\begin{array}{l}\text { Extraction of crude petroleum and } \\
\text { natural gas; service activities } \\
\text { incidental to oil and gas } \\
\text { extraction excluding surveying }\end{array}$ & $8.736^{* * *}$ & 0.103 & $8.746 * * *$ & 0.062 & $9.121^{* * *}$ & 0.033 \\
\hline $\begin{array}{l}\text { Mining of uranium and thorium } \\
\text { ores }\end{array}$ & n.a. & & n.a. & & n.a. & \\
\hline Mining of metal ores & $9.103^{* * *}$ & 0.175 & $8.289 * * *$ & 0.079 & $8.809 * * *$ & 0.030 \\
\hline Other mining and quarrying & $8.007^{* * *}$ & 0.098 & $8.102 * * *$ & 0.092 & $8.459 * * *$ & 0.045 \\
\hline $\begin{array}{l}\text { Manufacture of food products } \\
\text { and beverages }\end{array}$ & $7.885^{* * *}$ & 0.033 & $7.946 * * *$ & 0.027 & $8.270 * * *$ & 0.014 \\
\hline Manufacture of tobacco products & $7.770 * * *$ & 0.056 & $7.936 * * *$ & 0.039 & $8.242^{* * *}$ & 0.026 \\
\hline Manufacture of textiles & $7.915^{* * *}$ & 0.034 & $7.927 * * *$ & 0.031 & $8.233 * * *$ & 0.017 \\
\hline
\end{tabular}


Table 4. Continued

\begin{tabular}{|c|c|c|c|c|c|c|}
\hline \multirow[t]{2}{*}{ Industry } & \multicolumn{2}{|c|}{2000} & \multicolumn{2}{|c|}{2005} & \multicolumn{2}{|c|}{2010} \\
\hline & IWP & Std. err. & IWP & Std. err. & IWP & Std. err. \\
\hline Manufacture of wearing apparel & $7.938 * * *$ & 0.035 & $8.017^{* * *}$ & 0.026 & $8.327 * * *$ & 0.017 \\
\hline $\begin{array}{l}\text { Tanning and dressing of leather; } \\
\text { manufacture of luggage, } \\
\text { handbags, saddlery, harness } \\
\text { and footwear }\end{array}$ & $7.957^{* * *}$ & 0.049 & $7.976 * * *$ & 0.045 & $8.406^{* * *}$ & 0.027 \\
\hline $\begin{array}{l}\text { Manufacture of wood and } \\
\text { products of wood and cork, } \\
\text { except furniture; manufacture } \\
\text { of articles of straw and plaiting } \\
\text { materials }\end{array}$ & $8.011^{* * *}$ & 0.037 & $7.977^{* * *}$ & 0.029 & $8.332 * * *$ & 0.022 \\
\hline $\begin{array}{l}\text { Manufacture of paper and paper } \\
\text { products }\end{array}$ & $8.251^{* * *}$ & 0.113 & $8.114^{* * *}$ & 0.062 & $8.554^{* * *}$ & 0.033 \\
\hline $\begin{array}{l}\text { Publishing, printing and } \\
\text { reproduction of recorded media }\end{array}$ & $8.002 * * *$ & 0.063 & $7.961 * * *$ & 0.044 & $8.341^{* * *}$ & 0.029 \\
\hline $\begin{array}{l}\text { Manufacture of coke, refined } \\
\text { petroleum products and } \\
\text { nuclear fuel }\end{array}$ & $8.960 * * *$ & 0.143 & $8.438 * * *$ & 0.098 & $9.177^{* * *}$ & 0.077 \\
\hline $\begin{array}{l}\text { Manufacture of chemicals and } \\
\text { chemical products }\end{array}$ & $8.011^{* * *}$ & 0.063 & $8.223^{* * *}$ & 0.044 & $8.646 * * *$ & 0.028 \\
\hline $\begin{array}{l}\text { Manufacture of rubber and } \\
\text { plastics products }\end{array}$ & $7.977 * * *$ & 0.060 & $8.027^{* * *}$ & 0.039 & $8.471^{* * *}$ & 0.027 \\
\hline $\begin{array}{l}\text { Manufacture of other non- } \\
\text { metallic mineral products }\end{array}$ & $7.865^{* * *}$ & 0.049 & $7.933^{* * *}$ & 0.041 & $8.266^{* * *}$ & 0.028 \\
\hline Manufacture of basic metals & $8.205^{* * *}$ & 0.082 & $8.254^{* * *}$ & 0.057 & $8.772 * * *$ & 0.041 \\
\hline $\begin{array}{l}\text { Manufacture of fabricated metal } \\
\text { products, except machinery and } \\
\text { equipment }\end{array}$ & $7.990 * * *$ & 0.062 & $7.856 * * *$ & 0.070 & $8.330 * * *$ & 0.029 \\
\hline $\begin{array}{l}\text { Manufacture of machinery and } \\
\text { equipment n.e.c. }\end{array}$ & $8.473^{* * *}$ & 0.160 & $8.019 * * *$ & 0.062 & $8.620 * * *$ & 0.047 \\
\hline $\begin{array}{l}\text { Manufacture of office, accounting } \\
\text { and computing machinery }\end{array}$ & $8.277^{* * *}$ & 0.319 & $8.153^{* * *}$ & 0.201 & $8.823^{* * *}$ & 0.151 \\
\hline $\begin{array}{l}\text { Manufacture of electrical } \\
\text { machinery and apparatus n.e.c. }\end{array}$ & $7.855^{* * *}$ & 0.148 & $8.214^{* * *}$ & 0.079 & $8.602^{* * *}$ & 0.062 \\
\hline $\begin{array}{l}\text { Manufacture of radio, television } \\
\text { and communication equipment } \\
\text { and apparatus }\end{array}$ & $8.094 * * *$ & 0.062 & $8.286 * * *$ & 0.059 & $8.900 * * *$ & 0.022 \\
\hline $\begin{array}{l}\text { Manufacture of medical, precision } \\
\text { and optical instruments, } \\
\text { watches and clocks }\end{array}$ & $7.958 * * *$ & 0.390 & $7.974 * * *$ & 0.232 & $8.674^{* * *}$ & 0.119 \\
\hline $\begin{array}{l}\text { Manufacture of motor vehicles, } \\
\text { trailers and semi-trailers }\end{array}$ & $8.241^{* * *}$ & 0.086 & $8.379 * * *$ & 0.058 & $8.782 * * *$ & 0.055 \\
\hline
\end{tabular}


Table 4. Continued

\begin{tabular}{|c|c|c|c|c|c|c|}
\hline \multirow[t]{2}{*}{ Industry } & \multicolumn{2}{|c|}{2000} & \multicolumn{2}{|c|}{2005} & \multicolumn{2}{|c|}{2010} \\
\hline & IWP & Std. err. & IWP & Std. err. & IWP & Std. err. \\
\hline $\begin{array}{l}\text { Manufacture of other transport } \\
\text { equipment }\end{array}$ & $8.354 * * *$ & 0.167 & $8.264^{* * *}$ & 0.112 & $8.664 * * *$ & 0.033 \\
\hline $\begin{array}{l}\text { Manufacture of furniture, } \\
\text { manufacturing n.e.c. }\end{array}$ & $7.870 * * *$ & 0.038 & $7.862^{* * *}$ & 0.038 & $8.277^{* * *}$ & 0.019 \\
\hline $\begin{array}{l}\text { Electricity, gas, steam and } \\
\text { hot water supply }\end{array}$ & n.a. & & n.a. & & n.a. & \\
\hline Other business activities & $7.982 * * *$ & 0.061 & $8.050 * * *$ & 0.054 & $8.538 * * *$ & 0.029 \\
\hline $\begin{array}{l}\text { Recreational, cultural and } \\
\text { sporting activities }\end{array}$ & $7.919 * * *$ & 0.088 & $8.109 * * *$ & 0.059 & $8.502 * * *$ & 0.027 \\
\hline Other service activities & $7.841^{* * *}$ & 0.037 & $7.872 * * *$ & 0.035 & $8.201 * * *$ & 0.014 \\
\hline $\begin{array}{l}\text { Extra-territorial organisations and } \\
\text { bodies }\end{array}$ & n.a. & & $7.182^{* * *}$ & 0.566 & $8.397 * * *$ & 0.122 \\
\hline Standard deviation & 0.336 & & 0.254 & & 0.271 & \\
\hline Correlation with share of unskilled & -0.180 & & -0.269 & & -0.405 & \\
\hline
\end{tabular}

Note: $* \mathrm{p}<.05,{ }^{* *} \mathrm{p}<.01, * * * \mathrm{p}<.001 ; \mathrm{n} . \mathrm{a} .-$ indicate no workers in the industry; n.e.c. - not elsewhere classified.

Source: Authors' calculations based on SAKERNAS datasets.

Table 5. Correlation matrix for industry wage premiums

\begin{tabular}{llll}
\hline & 2000 & 2005 & 2010 \\
\hline 2000 & 1 & & \\
2005 & $0.683^{* * *}$ & 1 & \\
2010 & $0.775^{* * *}$ & $0.752 * * *$ & 1 \\
\hline
\end{tabular}

Note: $\quad * \mathrm{p}<.05 ; * * \mathrm{p}<.01 ; * * * \mathrm{p}<.001$

Source: Base on authors' calculations of inter-industry wage premiums.

Table 5 shows year-to-year correlations on the industry wage premiums composition which has not shifted much over time. The correlation between the industry wage premiums in 2000 and 2005 is 0.683 , and 0.775 for the relations between 2000 and 2010. The significant value of industry wage premiums implies that the interindustry composition has not shifted over time.

\subsection{Industry-specific Skill Premiums}

Results of the first stage, as seen in Table 6, indicate that for the industry-specific skill premiums, definite skills are possibly significant. All coefficients of industry-specific skill premiums are positive. This suggests that in all industries, university-educated workers have higher wages than those with lower education levels. 
Table 6. Industry-specific skill premiums, 2000, 2005 and 2010

\begin{tabular}{|c|c|c|c|c|c|c|}
\hline \multirow[t]{2}{*}{ Industry } & \multicolumn{2}{|c|}{2000} & \multicolumn{2}{|c|}{2005} & \multicolumn{2}{|c|}{2010} \\
\hline & Coef. & Std. err. & Coef. & Std. err. & Coef. & Std. err. \\
\hline $\begin{array}{l}\text { Agriculture, hunting and related } \\
\text { service activities }\end{array}$ & $1.162 * * *$ & 0.188 & $1.214 * * *$ & 0.160 & $1.168 * * *$ & 0.068 \\
\hline $\begin{array}{l}\text { Forestry, logging and related } \\
\text { service activities }\end{array}$ & n.a & & $1.636 * * *$ & 0.315 & $1.110 * * *$ & 0.135 \\
\hline $\begin{array}{l}\text { Fishing, operation of fish } \\
\text { hatcheries and fish farms; } \\
\text { service activities incidental to } \\
\text { fishing }\end{array}$ & $0.687^{*}$ & 0.395 & $1.388 * * *$ & 0.333 & $1.233^{* * *}$ & 0.143 \\
\hline $\begin{array}{l}\text { Mining of coal and lignite; } \\
\text { extraction of peat }\end{array}$ & $0.000 * * *$ & 0.000 & $1.395 * * *$ & 0.220 & $0.896 * * *$ & 0.089 \\
\hline $\begin{array}{l}\text { Extraction of crude petroleum and } \\
\text { natural gas; service activities } \\
\text { incidental to oil and gas } \\
\text { extraction excluding surveying }\end{array}$ & $0.639 * *$ & 0.296 & $1.287 * * *$ & 0.127 & $1.412 * * *$ & 0.068 \\
\hline $\begin{array}{l}\text { Mining of uranium and thorium } \\
\text { ores }\end{array}$ & n.a. & & n.a. & & n.a. & \\
\hline Mining of metal ores & $1.220 * *$ & 0.579 & $1.279 * * *$ & 0.296 & $1.311^{* * *}$ & 0.095 \\
\hline Other mining and quarrying & n.a & & 0.634 & 0.412 & $1.297^{* * *}$ & 0.225 \\
\hline $\begin{array}{l}\text { Manufacture of food products } \\
\text { and beverages }\end{array}$ & $1.277 * * *$ & 0.137 & $1.319 * * *$ & 0.092 & $1.122 * * *$ & 0.056 \\
\hline Manufacture of tobacco products & $1.264 * * *$ & 0.395 & $1.159 * * *$ & 0.221 & $0.918 * * *$ & 0.099 \\
\hline Manufacture of textiles & $1.006 * * *$ & 0.111 & $1.421 * * *$ & 0.124 & $1.140 * * *$ & 0.079 \\
\hline Manufacture of wearing apparel & $0.753 * * *$ & 0.214 & $1.264 * * *$ & 0.109 & $1.178 * * *$ & 0.082 \\
\hline $\begin{array}{l}\text { Tanning and dressing of leather; } \\
\text { manufacture of luggage, } \\
\text { handbags, saddlery, harness } \\
\text { and footwear }\end{array}$ & $1.097 * * *$ & 0.233 & $1.470 * * *$ & 0.189 & $0.979 * * *$ & 0.128 \\
\hline $\begin{array}{l}\text { Manufacture of wood and } \\
\text { products of wood and cork, } \\
\text { except furniture; manufacture } \\
\text { of articles of straw and plaiting } \\
\text { materials }\end{array}$ & $0.721 * * *$ & 0.161 & $1.303 * * *$ & 0.153 & $1.091 * * *$ & 0.095 \\
\hline $\begin{array}{l}\text { Manufacture of paper and } \\
\text { paper products }\end{array}$ & $0.904 * *$ & 0.407 & $1.238 * * *$ & 0.242 & $0.993 * * *$ & 0.101 \\
\hline $\begin{array}{l}\text { Publishing, printing and } \\
\text { reproduction of recorded media }\end{array}$ & $0.658 * * *$ & 0.188 & $1.010 * * *$ & 0.116 & $1.132 * * *$ & 0.067 \\
\hline $\begin{array}{l}\text { Manufacture of coke, refined } \\
\text { petroleum products and } \\
\text { nuclear fuel }\end{array}$ & 0.458 & 0.570 & $2.444 * * *$ & 0.180 & $1.369 * * *$ & 0.149 \\
\hline $\begin{array}{l}\text { Manufacture of chemicals and } \\
\text { chemical products }\end{array}$ & $1.046 * * *$ & 0.135 & $1.517^{* * *}$ & 0.110 & $1.190 * * *$ & 0.064 \\
\hline
\end{tabular}


Table 6. Continued

\begin{tabular}{|c|c|c|c|c|c|c|}
\hline \multirow[t]{2}{*}{ Industry } & \multicolumn{2}{|c|}{2000} & \multicolumn{2}{|c|}{2005} & \multicolumn{2}{|c|}{2010} \\
\hline & Coef. & Std. err. & Coef. & Std. err. & Coef. & Std. err. \\
\hline $\begin{array}{l}\text { Manufacture of rubber and } \\
\text { plastics products }\end{array}$ & $1.197^{* * *}$ & 0.256 & $1.470 * * *$ & 0.196 & $1.172^{* * *}$ & 0.099 \\
\hline $\begin{array}{l}\text { Manufacture of other non- } \\
\text { metallic mineral products }\end{array}$ & $1.620 * * *$ & 0.253 & $1.339 * * *$ & 0.160 & $1.331^{* * *}$ & 0.113 \\
\hline Manufacture of basic metals & $1.013^{* *}$ & 0.400 & $1.237^{* * *}$ & 0.241 & $1.373 * * *$ & 0.104 \\
\hline $\begin{array}{l}\text { Manufacture of fabricated metal } \\
\text { products, except machinery and } \\
\text { equipment }\end{array}$ & $1.048^{* * *}$ & 0.396 & $1.772 * * *$ & 0.336 & $1.374^{* * *}$ & 0.138 \\
\hline $\begin{array}{l}\text { Manufacture of machinery and } \\
\text { equipment n.e.c. }\end{array}$ & $1.489 * * *$ & 0.278 & $1.269 * * *$ & 0.335 & $1.268 * * *$ & 0.143 \\
\hline $\begin{array}{l}\text { Manufacture of office, accounting } \\
\text { and computing machinery }\end{array}$ & $1.491^{* * *}$ & 0.504 & $1.880 * * *$ & 0.449 & $0.863 * *$ & 0.370 \\
\hline $\begin{array}{l}\text { Manufacture of electrical } \\
\text { machinery and apparatus n.e.c. }\end{array}$ & $0.971^{*}$ & 0.572 & $1.146^{* * *}$ & 0.232 & $0.964 * * *$ & 0.187 \\
\hline $\begin{array}{l}\text { Manufacture of radio, television } \\
\text { and communication equipment } \\
\text { and apparatus }\end{array}$ & $1.356 * * *$ & 0.235 & $1.302 * * *$ & 0.158 & $1.007 * * *$ & 0.092 \\
\hline $\begin{array}{l}\text { Manufacture of medical, precision } \\
\text { and optical instruments, } \\
\text { watches and clocks }\end{array}$ & n.a. & & $1.691 * * *$ & 0.464 & $1.235^{* * *}$ & 0.430 \\
\hline $\begin{array}{l}\text { Manufacture of motor vehicles, } \\
\text { trailers and semi-trailers }\end{array}$ & $1.176 * * *$ & 0.215 & $1.433^{* * *}$ & 0.166 & $0.727^{* * *}$ & 0.161 \\
\hline $\begin{array}{l}\text { Manufacture of other transport } \\
\text { equipment }\end{array}$ & $1.527^{* * *}$ & 0.361 & $1.428 * * *$ & 0.222 & $1.279 * * *$ & 0.102 \\
\hline $\begin{array}{l}\text { Manufacture of furniture, } \\
\text { manufacturing n.e.c. }\end{array}$ & $1.000 * * *$ & 0.161 & $1.331^{* * *}$ & 0.166 & $1.183^{* * *}$ & 0.092 \\
\hline $\begin{array}{l}\text { Electricity, gas, steam and hot } \\
\text { water supply }\end{array}$ & n.a. & & n.a. & & n.a. & \\
\hline Other business activities & $1.143^{* * *}$ & 0.113 & $1.355^{* * *}$ & 0.091 & $1.147^{* * *}$ & 0.051 \\
\hline $\begin{array}{l}\text { Recreational, cultural and sporting } \\
\text { activities }\end{array}$ & 0.389 & 0.244 & $1.116^{* * *}$ & 0.129 & $0.977^{* * *}$ & 0.057 \\
\hline Other service activities & $0.609 * * *$ & 0.161 & $1.068 * * *$ & 0.131 & $1.025 * * *$ & 0.056 \\
\hline $\begin{array}{l}\text { Extra-territorial organisations and } \\
\text { bodies }\end{array}$ & n.a & & $2.871^{* * *}$ & 0.655 & $1.305^{* * *}$ & 0.194 \\
\hline Standard deviation & 0.326 & & 0.396 & & 0.169 & \\
\hline $\begin{array}{l}\mathrm{R}^{2} \text { change for industry-specific skill } \\
\text { premium }\end{array}$ & 0.01 & & 0.01 & & 0.01 & \\
\hline
\end{tabular}

Note: $* \mathrm{p}<.05, * * \mathrm{p}<.01, * * * \mathrm{p}<.001 ; \mathrm{n} . \mathrm{a} .-$ indicate no skilled worker in the industry; n.e.c. - not elsewhere classified.

Source: Authors' calculations based on SAKERNAS datasets. 
The industry-specific skill premiums does not raise the regression explanatory power; though, the premiums differ broadly across industries. Highly educated workers in other non-metallic mineral products manufacture earn the highest skill premiums while those in entertainment (recreational), cultural and sporting industries earn the lowest. The standard deviation of industry-specific skill premiums ability is between 0.169 and 0.396 from 2000-2010.

\subsection{Tariffs and Industry Wage Premiums}

The estimated regressions of industry wage premiums on tariff is shown in Table 7. Labour qualities are controlled in the first phase regression. This renders the relationship between wage premiums and tariffs free from worker composition differences which may influence the results on its impact on trade liberalisation. Since returns to labour qualities are allowed to vary over years in the first phase, the coefficients reflect shifts in the labour market that are connected to shifts in worker supply. The second stage regression is estimated in level including the year indicator. The estimation is also done in first differences to account for the unmonitored time-invariant changes, particularly those due to negotiating power and macroeconomic jolts that may affect wages and tariffs simultaneously.

The study regresses industry wage premium models for 2000, 2005 and 2010 with various specifications: column (1) for pooled least squares, (2) for fixed effect, (3) for random effect and (7) pooled least squares for first differences and regressions for 2000 and 2010: column (4) for pooled least squares, (5) for fixed effect and (6)

Table 7. Second stage result: tariffs and industry wage premiums

\begin{tabular}{|c|c|c|c|c|c|c|c|c|}
\hline & & (1) & (2) & (3) & (4) & (5) & (6) & (7) \\
\hline \multirow[t]{3}{*}{ Tarif } & Coefficient & -0.016 & -0.035 & -0.017 & -0.025 & -0.025 & -0.025 & -0.036 \\
\hline & Standard error & 0.008 & 0.028 & 0.009 & 0.010 & 0.055 & 0.011 & 0.020 \\
\hline & P-Value & 0.041 & 0.207 & 0.070 & 0.017 & 0.652 & 0.020 & 0.071 \\
\hline \multirow[t]{3}{*}{ Constant } & Coefficient & 8.364 & 8.506 & 8.370 & 8.519 & 8.521 & 8.519 & 0.220 \\
\hline & Standard error & 0.065 & 0.201 & 0.079 & 0.083 & 0.386 & 0.088 & 0.041 \\
\hline & P-Value & 0.000 & 0.000 & 0.000 & 0.000 & 0.000 & 0.000 & 0.000 \\
\hline \multicolumn{2}{|c|}{ Breusch and Pagan LM test } & \multicolumn{3}{|c|}{ Chi-Sq= $0.00(p=1.00)$} & \multicolumn{4}{|c|}{ Chi-Sq $=0.59(p=0.22)$} \\
\hline \multicolumn{2}{|c|}{ Hausman specification test } & \multicolumn{3}{|c|}{ Chi-Sq= $0.03(p=0.87)$} & \multicolumn{4}{|c|}{ Chi-Sq= $0.03(p=0.87)$} \\
\hline \multicolumn{2}{|l|}{ Chi-Sq } & - & - & 3.283 & & \multicolumn{3}{|c|}{5.411} \\
\hline \multicolumn{2}{|c|}{ P-Value (Chi-Sq) } & - & - & 0.07 & & \multicolumn{3}{|c|}{0.02} \\
\hline \multicolumn{2}{|c|}{ Observations } & 98 & 98 & 98 & & 65 & 65 & 65 \\
\hline \multicolumn{2}{|l|}{$R_{\text {adj }}^{2}$} & 0.033 & -0.478 & - & 0.073 & -1.051 & - & 0.036 \\
\hline \multicolumn{2}{|l|}{ F-Stat } & 4.272 & 1.627 & - & 6.010 & 0.210 & - & 3.38 \\
\hline \multicolumn{2}{|c|}{ P-Value (F) } & 0.0414 & 0.2067 & - & 0.017 & 0.652 & - & 0.071 \\
\hline
\end{tabular}

Note: Columns (1) - (3), (7) for 2000, 2005 and 2010, (4) - (6) for 2000 and 2010.

Source: Authors' calculations based on SAKERNAS datasets. 
for random effect. Based on the Breusch Pagan test, the best model was pooled least squares ( $p=1.00$ for 2000, 2005 and 2010 and $p=0.22$ for 2000 and 2010). For the robustness, a fixed effect model and a random effect are estimated. Based on the Hausman test, the best model is the random effect model ( $p=0.87$ for 2000,2005 and 2010 and $p=0.87$ for 2000 and 2010). In addition, a model for the differences is also estimated (column 7).

The coefficient on tariffs remains negative and statistically significant (at least at the 10 percent level) except in fixed effect models. The result shows a connection between salary premiums and tariffs. The industry wage premium is a necessary part of labour wages which is related to trade policies. The coefficient is negative, indicating that tariff increase decreases industry wage. This value is in line with studies of Kumar and Mishra (2008), and Mehta and Hasan (2012).

Discussions on wage variety of inter-industries have neglected the part of worker market bodies including minimum wages and union power which may influence the findings. The minimum wages are regulated not to differ across industrial sectors. This affects the coefficients of education indicators on the initial phase, in which it is tied up to the low-wage workers. Factors that change the minimum wages might be on the structural channel, as an example due to the employment of many unskilled workers by some industries. These factors are controlled since the industrial structure on the first phase regressions allows the returns of diverse education levels to change over years.

Second, there is no information about union membership found in the individuallevel data, meanwhile alterations in unions do not encourage the industry wage premium yields. Only if alterations in union power turn in the same way that tariff turns by industry, alterations in the unions may influence the industry stipends independently of the modification of tariff; this possibly biases the results. As far as the strength of unions in each industry does not change during the time in Indonesia, the first difference of data will seize the consequences of unions. This becomes a sensible presumption. Arbache and Carneiro (1999) notified union stocks in different manufacturing industries between 1992 and 1995. Their findings informed that stocks are relatively constant over time. In addition, no studies have shown that alterations in union power are related to shifts in tariffs.

\subsection{Tariffs and Industry-specific Skill Premiums}

Are these changes in industry-specific skill premiums associated with trade liberalisation? Table 8 shows regression result of tariffs and industry-specific skill premiums models for 2000, 2005 and 2010 with various specifications: column (1) for pooled least squares, (2) for fixed effect, (3) for random effect and (7) pooled least squares for first differences and regressions for 2000 and 2010: column (4) for pooled least square, (5) for fixed effect and (6) for random effect. Tariffs and industry-specific skill premiums are not statistically associated based on the regression results.

Commonly, tariff influencing the wages in Indonesia through industry associations proved to be statistically significant. However, there is no statistically significant evidence to suggest that tariff affects wage dissimilarities between skilled and unskilled labours through this channel. 
Table 8. Second stage result: tariffs and industry-specific skill premiums

\begin{tabular}{|c|c|c|c|c|c|c|c|c|}
\hline & & (1) & (2) & (3) & (4) & (5) & (6) & (7) \\
\hline \multirow[t]{3}{*}{ Tarif } & Coefficient & -0.003 & 0.035 & -0.002 & -0.005 & -0.027 & -0.005 & -0.002 \\
\hline & Standard error & 0.008 & 0.031 & 0.008 & 0.008 & 0.046 & 0.008 & 0.009 \\
\hline & P-Value & 0.726 & 0.274 & 0.781 & 0.529 & 0.566 & 0.527 & 0.880 \\
\hline \multirow[t]{3}{*}{ Constant } & Coefficient & 1.226 & 0.953 & 1.224 & 1.127 & 1.285 & 1.127 & 1.186 \\
\hline & Standard error & 0.066 & 0.232 & 0.071 & 0.063 & 0.332 & 0.063 & 0.084 \\
\hline & P-Value & 0.000 & 0.000 & 0.000 & 0.000 & 0.001 & 0.000 & 0.000 \\
\hline \multicolumn{2}{|c|}{ Breusch and Pagan LM test } & \multicolumn{3}{|c|}{ Chi-Sq $=0.200(p=0.298)$} & \multicolumn{4}{|c|}{ Chi-Sq $=0.59(p=0.221)$} \\
\hline \multicolumn{2}{|c|}{ Hausman specification test } & Chi-Sq & $1.48(p=$ & 224) & \multicolumn{3}{|c|}{ Chi-Sq= $1.23(p=0.629)$} & \\
\hline \multicolumn{2}{|l|}{ Chi-Sq } & & & 0.077 & & & 5.400 & \\
\hline \multicolumn{2}{|c|}{ P-value (Chi-Sq) } & & & 0.781 & & & 0.020 & \\
\hline \multicolumn{2}{|c|}{ Observations } & 94 & 94 & 94 & 61 & 61 & 61 & 61 \\
\hline \multicolumn{2}{|c|}{ Adjusted $\mathrm{R}^{2}$} & -0.01 & -0.519 & & -0.010 & -1.195 & & 0.004 \\
\hline \multicolumn{2}{|l|}{ F-Stat } & 0.123 & 1.218 & & 0.400 & 0.337 & & 0.020 \\
\hline \multicolumn{2}{|c|}{ P-Value (F) } & 0.726 & 0.274 & & 0.529 & 0.566 & & 0.880 \\
\hline
\end{tabular}

Note: Columns (1) - (3), (7) for 2000, 2005 and 2010, (4) - (6) for 2000 and 2010.

Source: Authors' calculations based on SAKERNAS datasets.

\section{Conclusion}

Recent policy debates on the advantages and expenses of trade reforms motivate this study. Many people query the feasible advantages of trade liberalisation; whether improvements in efficiency and wellbeing are greater than the possible expenses of expanding dissimilarity, and 'down racing' in wages. Several researches suggested utilising labour market policies, such as minimum wages and government social protection programs to balance the possible rise in dissimilarities connected to trade liberalisation (Goldberg \& Pavcnik, 2007; Jayanthakumaran, Sangkaew, \& O’Brien, 2013; Kumar \& Mishra, 2008; Mehta \& Hasan, 2012).

There are a few contributions provided by this study. First, it focusses on trade policy variables (such as tariffs) in evaluating the complicity of trade reforms on the labour market. The use of outcome variables has made it difficult to assess the effects of trade liberalisation. Employing outcome variables, such as openness, in assessing trade reforms will portray not only the trade policies of a country but also factors such as transportation charges, technology, demand and factor price changes (Rodriguez \& Rodrik, 2000). Thus, it is beneficial to employ trade policy variables.

Second, those who oppose globalisation declare that trade reforms cause workers of the protected sectors to become poorer; and trade liberalisation drives wages downward. Several researches support this claim. Among others, Goldberg and Pavcnik (2005) and Revenga (1997) found that tariff reductions were connected to a decrease in inter-industry wage differences in Colombia and Mexico. Goldberg and Pavcnik (2007) 
and Rama (2001) presented proofs of a negative relationship between openness and wages in the short term in cross-country studies. Evidence from Indonesia shows that trade liberalisation does not necessarily lower wages through industry wage premium channels. Trade liberalisation can lower wages through other channels, such as lesser return for education or experience, but is not the focus of this research. Various characteristics of the country that specify how the reforms of trade influence the wages through different channels can be a field of research in the future.

Finally, the evidence shows that trade liberalisation exacerbates wage inequality through shifts in industrial wage structures. However, the industry wage premium in Indonesia diverges greatly. The industry's smallest premium is in sectors with high unskilled labour stocks. This shows that unskilled labours receive low wages not only due to the economic skill premium growth but also because a disproportionate number work in industry with low wage premiums. This is an inequality that has not been detected in prior researches. The inequality and enhancement of skill premiums can be dealt with through policies of the labour market, such as those suggested by Martins (2004) by shifting the minimum wages and building social safety programmes, besides increasing access to education.

\section{References}

Acemoglu, D. (2003). Patterns of skill premia. The Review of Economic Studies, 70(2), 199-230. https://doi.org/10.1111/1467-937X.00242

Amiti, M., \& Cameron, L. (2012). Trade liberalization and the wage skill premium: Evidence from Indonesia. Journal of International Economics, 87(2), 277-287. https://doi.org/10.1016/ j.jinteco.2012.01.009

Amiti, M., \& Konings, J. (2007). Trade liberalization, intermediate input, and productivity: Evidence from Indonesia. American Economic Review, 97(5), 1611-1638. https://doi.org/10.1257/ aer.97.5.1611

Arbache, J.S., \& Carneiro, F.G. (1999). Unions and interindustry wage differentials. World Development, 27(10), 1875-1883. https://doi.org/10.1016/S0305-750X(99)00090-X

Attanasio, O., Goldberg, P.K., \& Pavcnik, N. (2004). Trade reforms and wage inequality in Colombia. Journal of Development Economics, 74(2), 331-366. https://doi.org/10.1016/ j.jdeveco.2003.07.001

Basri, M.C., \& Patunru, A.A. (2012). How to keep trade policy open: The case of Indonesia. Bulletin of Indonesian Economic Studies, 48(2), 191-208. https://doi.org/10.1080/00074918. 2012.694154

Badan Pusat Statistik (BPS). (2000). Survei angkatan kerja nasional Agustus 2000 (pedoman pencacah). Jakarta: Author.

Badan Pusat Statistik (BPS). (2005). Survei angkatan kerja nasional Agustus 2005 (pedoman pencacah). Jakarta: Author.

Badan Pusat Statistik (BPS). (2010). Survei angkatan kerja nasional Agustus 2010 (pedoman pencacah). Jakarta: Author.

Badan Pusat Statistik (BPS). (2015). Statistik 70 tahun Indonesia merdeka. Jakarta: Author.

Baldwin, R.E. (1971). Determinants of the commodity structure of US trade. The American Economic Review, 61(1), 126-146.

Cragg, M.I., \& Epelbaum, M. (1995). Why has wage dispersion grown in Mexico? Is it the incidence of reforms or the growing demand for skills? (Discussion Paper Series No. 740) New York: Columbia University. 
De Locker, J. (2007). Product differentiation, multi-product firms and estimating the impact of trade liberalization on productivity (NBER Working Paper Series, No. 13155). Cambridge, MA: National Bureau of Economic Research. https://doi.org/10.3386/w13155

Eslava, M., Haltiwanger, J., Kugler, A., \& Kugler, M. (2013). Trade and market selection: Evidence from manufacturing plants in Colombia. Review of Economic Dynamics, 16(1), 135-158. https://doi.org/10.1016/j.red.2012.10.009

Feenstra, R.C., \& Hanson, G.H. (2001). Global production sharing and rising inequality: A survey of trade and wages (NBER Working Paper Series, No. 8372). Cambridge, MA: National Bureau of Economic Research. https://doi.org/10.3386/w8372

Ferreira, F.H.G., Leite, P.G., Wai-Poi, M. (2007). Trade liberalization, employment flows and wage inequality in Brazil (World Institute for Development Economics Research (WIDER) Working Paper No. 58). Helsinki: WIDER. https://doi.org/10.1596/1813-9450-4108

Galiani, S., \& Sanguinetti, P. (2003). The impact of trade liberalization on wage inequality: Evidence from Argentina. Journal of Development Economics, 72(2), 497-513. https://doi. org/10.1016/S0304-3878(03)00117-2

Goldberg, P.K., \& Pavcnik, N. (2005). Trade, wages, and the political economy of trade protection: Evidence from the Colombian trade reforms. Journal of International Economics, 66(1), 75105. https://doi.org/10.1016/j.jinteco.2004.04.005

Goldberg, P.K., \& Pavcnik, N. (2007). Distributional effects of globalization in developing countries. Journal of Economic Literature, 45(1), 39-82. https://doi.org/10.1257/jel.45.1.39

Gonzaga, G., Menezes Filho, N., \& Terra, C. (2006). Trade liberalization and the evolution of skill earnings differentials in Brazil. Journal of International Economics, 68(2), 345-367. https:// doi.org/10.1016/j.jinteco.2005.07.008

Harrison, A.E., Martin, L.A., \& Nataraj, S. (2012). Learning versus stealing: How important are market-share reallocations to India's productivity growth? The World Bank Economic Review, 27(2), 202-228. https://doi.org/10.1093/wber/lhs029

Jacob, J., \& Meister, C. (2005). Productivity gains, technology spillovers and trade: Indonesian manufacturing, 1980-96. Bulletin of Indonesian Economic Studies, 41(1), 37-56. https://doi. org/10.1080/00074910500072674

Jayanthakumaran, K., Sangkaew, P., \& O'Brien, M. (2013). Trade liberalisation and manufacturing wage premiums: Evidence from Thailand. Journal of Asian Economics, 29(December), 15-23. https://doi.org/10.1016/j.asieco.2013.08.001

Kumar, U., \& Mishra, P. (2008). Trade liberalization and wage inequality: Evidence from India. Review of Development Economics, 12(2), 291-311. https://doi.org/10.1111/j.1467-9361.2007.00388.x

Lee, J-W., \& Wie, D. (2015). Technological change, skill demand, and wage inequality: Evidence from Indonesia. World Development, 67(March), 238-250. https://doi.org/10.1016/ j.worlddev.2014.10.020

Martins, P.S. (2004). Industry wage premia: Evidence from the wage distribution. Economics Letters, 83(2), 157-163. https://doi.org/10.1016/j.econlet.2003.11.002

Mehta, A., \& Hasan, R. (2012). The effects of trade and services liberalization on wage inequality in India. International Review of Economics and Finance, 23(June), 75-90. https://doi. org/10.1016/j.iref.2011.10.007

Melitz, M.J. (2003). The impact of trade on intra-industry reallocations and aggregate industry productivity. Econometrica, 71(6), 1695-1725. https://doi.org/10.1111/1468-0262.00467

Nataraj, S. (2011). The impact of trade liberalization on productivity: Evidence from India's formal and informal manufacturing sectors. Journal of International Economics, 85(2), 292-301. https://doi.org/10.1016/j.jinteco.2011.07.003

Pangestu, M., Rahardja, S., \& Ing, L.Y. (2015). Fifty years of trade policy in Indonesia: New world trade, old treatments. Bulletin of Indonesian Economic Studies, 51(2), 239-261. https://doi. org/10.1080/00074918.2015.1061915 
Pavcnik, N., Blom, A., Goldberg, P., \& Schady, N. (2004). Trade liberalization and industry wage structure: Evidence from Brazil. The World Bank Economic Review, 18(3), 319-344. https:// doi.org/10.1093/wber//hh045

Rama, M. (2001). Globalization, inequality and labor market policies. Paper presented the European on-line Annual World Bank Conference in Development Economics (ABCDE-Europe).

Revenga, A. (1997). Employment and wage effects of trade liberalization: The case of Mexican manufacturing. Journal of Labor Economics, 15(S3), S20-S43. https://doi.org/10.1086/209875

Robbins, D.J. (1996). Evidence on trade and wages in the developing world (OECD Development Centre Working Paper, No. 119). Paris: OECD Development Centre. https://doi.org/10.1787/ 18151949

Rodriguez, F., \& Rodrik, D. (2000). Trade policy and economic growth: A skeptic's guide to the cross-national evidence. NBER macroeconomics annual, 15, 261-325. https://doi. org/10.1086/654419

Rodrik, D. (1998). Has globalization gone too far? Challenge, 41(2), 81-94. https://doi.org/10.1080 /05775132.1998.11472025

Schwab, K., \& Sala-i-Martín, X. (2015). The global competitiveness report 2015-2016. Geneva: World Economic Forum.

Tadjoeddin, M.Z. (2016). Earnings, productivity and inequality in Indonesia. The Economic and Labour Relations Review, 27(2), 248-271. https://doi.org/ 10.1177/103530461664345

USAID. (June 2006). Developing country labor market adjustments to trade reform: An overview and resource guide. Arlington, VA: Nathan Associates Inc.

Wood, A. (1995). How trade hurt unskilled workers. The Journal of Economic Perspectives, 9(3), 57-80. https://doi.org/10.1257/jep.9.3.57

World Bank. (2014). Perkembangan triwulanan perekonomian Indonesia Desember 2014: Membawa perubahan. Jakarta: Author.

World Bank. (March 2016). Indonesia's rising divide (T.W.O. Jakarta, Trans.). Jakarta: Author. 
